\title{
Overview of falls in Brazilian public policies
}

| ${ }^{1}$ Renata Francielle dos Reis Fonseca, ${ }^{2}$ Silvia Matumoto |

Abstract: Public policies portray the proposals of actions on circumstances that affect the population unfavorably. Falls represent an important factor of morbidity and mortality and damage to aging. Thus, the objective of the research was to outline the panorama of falls in the governmental sphere by analyzing and identifying its relevance in official publications. The research, qualitative of document analysis, started with the content analysis of 14 documents and verified that falls are addressed concisely, in most of the documents, and aimed at health professionals. It is noteworthy that falls are highlighted as preventable occurrences and subject to intervention by the elderly themselves, family members, health professionals, and managers.

> Keywords: elderly; fall accidents; government document.

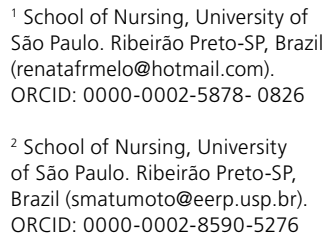

${ }^{2}$ School of Nursing, University of São Paulo. Ribeirão Preto-SP, Brazil (smatumoto@eerp.usp.br). ORCID: 0000-0002-8590-5276

Received in: 21/07/2019

Approved in: 03/03/2020 Revised in: 22/08/2021 


\section{Introduction}

The health care of the elderly requires a care model that has a design not only of intervention to the losses associated with senescence, but also to improve quality of life and well-being, access to care to strengthen and maintain functional capacity and psychosocial growth of the individual, the family and the community (TOLEDO et al., 2014; WHO, 2015).

Defined as the "unintentional displacement of the body to a level below the initial position, without timely correction", falls are events resulting from a complex interaction between intrinsic factors, such as physiological deficiencies resulting from aging or diseases and illnesses, and extrinsic factors, related to environmental risks (ARAUJO NETO et al., 2017, p. 753).

Falls in the elderly may cause functional disability, reduced autonomy and independence, impacting morbidity and mortality rates, quality of life and psychological and social damage in this age group. They also have consequences for families, caregivers, institutions and health systems, representing a public health problem despite research and preventive efforts (SHERRINGTON et al., 2016; STENHAGEN et al., 2014).

Research shows that there is exponential growth in mortality rates and hospital admissions throughout Brazil. Mortality rates between 1996 and 2012 had an increase of $200 \%$ in Brazilian capitals and an increase of $15 \%$ per year. Exemplifying the dimension of the problem, spending on hospital admissions of the elderly between the years 2005 and 2010, falls represented a cost of more than four hundred million reais (ABREU et al., 2018; BARROS et al, 2015).

Public health problems such as falls require public policies and normative legislation to solve them. Public policies are actions resulting from decisions and the elaboration of changes on determinants or phenomena that afflict the population. Governmental decision making is influenced by information, ideologies, international relations, the needs of the community, and political interests. Falls represent an important issue concerning health care in this age group, civil society, and public spending on health for the public good (MACEDO et al., 2016). Thus, an analysis and evaluation of public policies on falls is pertinent. These are intrinsic to all public policies in the sense of verifying the formulation process, the relevance of the objectives, and adjusting the results on the subjects of interest, as well as evaluating the implementation and increasing the actions to increase their success (FALSARELLA, 2015). 
In this sense, evidence indicates that the implementation of policies and programs to promote health, safety and participation of the elderly can enable the active aging of the population and in light of the above, this research seeks to outline the Brazilian official publications regarding falls in the elderly, understanding that reducing the incidence of falls involves the identification and implementation of preventive measures with multifactorial interventions (BAIXINHO; DIXE, 2016; RESENDE; LOPES; MANSO, 2018).

\section{Material and Method}

This is a qualitative and descriptive approach research of the Brazilian official publications of public access. Qualitative research is appropriate for the analysis of public policies due to its ability to understand the conceptions in the formulation of policies, such as their relevance, considering the current scientific evidence. The analysis starts from the determination of the problematization, the context, and the interventions that can achieve the resolutions (FALSARELLA, 2015).

In the document analysis, content analysis as a methodological tool outlined through a systematic activity the categorical classification in each document and for understanding that these provide on the theme. The content analysis was divided into three phases: pre-analysis; exploration of the material; data treatment and interpretation (SILVA; FOSSÁ, 2015):

Pre-analysis is the phase of organization and the glimpse of the theoretical framework. It began with a definition of the documental body to be analyzed, a superficial reading, and then proceeded to systematized ordering for the formulation of the representativeness of the documents about the target population and pertinence about the researched object in the selected documents. The successive and systematized reading allowed an approximation to the subjects addressed in the documents and their classification.

The material exploration phase consisted of coding tasks involving cutting the texts to choose the registration units, enumeration being the delimitation of the context to understand the units, and the classification of categories. In this phase, the sections or paragraphs that contained programming, goals, or descriptions in accordance with the selected themes were highlighted and transcribed in the file. The cue cards allowed a deeper reading and an evaluation as to the proposed goals, the insertion of the policy relative to the themes and the objective of this research (CAMARA, 2013). 
The treatment phase is consecutive to the interpretation of the results obtained in the previous phases, in which they are contemplated, pleaded and grouped. The approximation between the content addressed in the policies and scientific evidence allowed the inference, debate, and interpretation about the visualization of the governmental sphere. To synthesize the analysis, the results were exposed in tables when possible.

\section{Result}

The sources included published open public documents such as legislation, official statements and statistics, reference manuals and reports from government agencies, comprising government agencies within the Federal Union and the State of São Paulo, where the research was conducted.

The search for documents was conducted in: Virtual Health Library (VHL), Ministry of Health, State of São Paulo, Palácio do Planalto, Chamber of Deputies of the State of São Paulo. The descriptor used was: "elderly"; "aging".

\section{Figure 1. Flowchart of the the search for official documents related to the elderly}

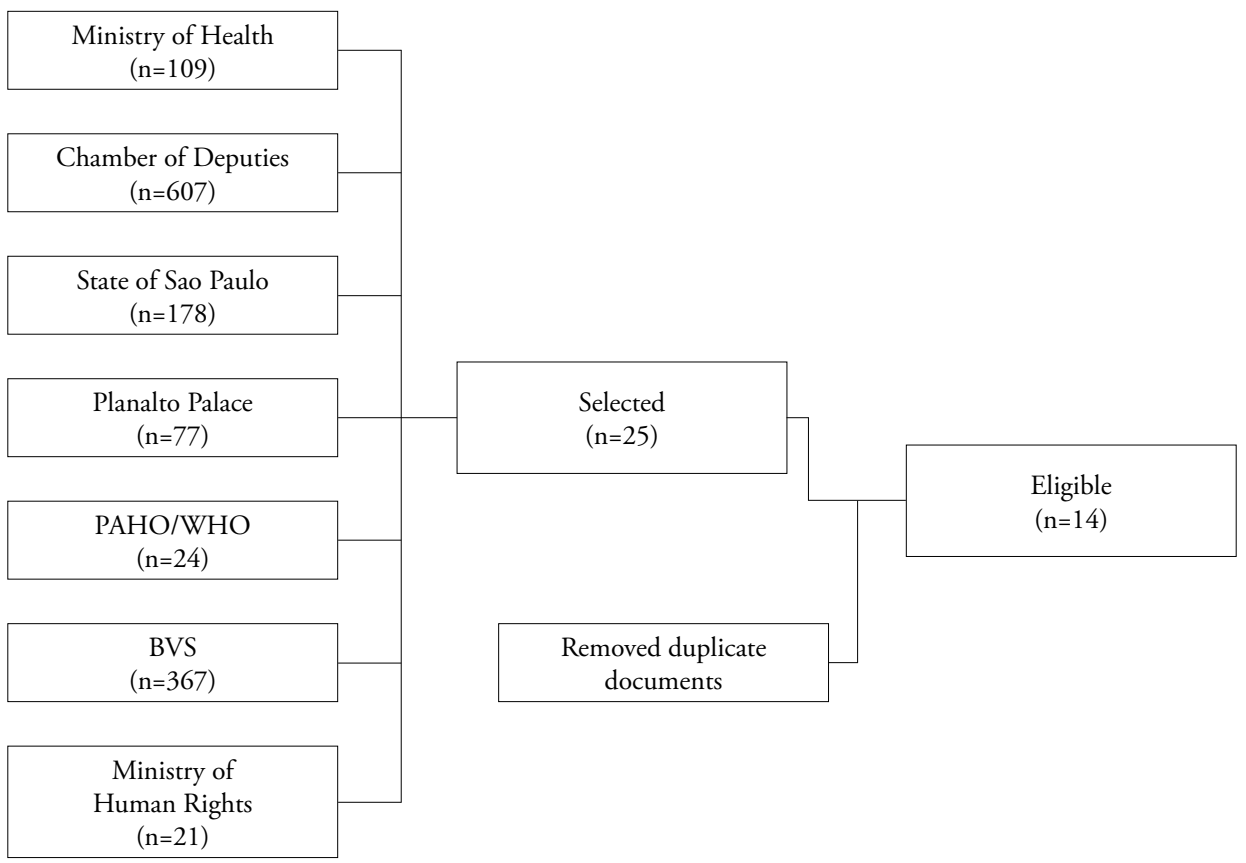


Table 1. Documents included according to name, purpose and ABNT citation. Ribeirão Preto-SP, 2019

\begin{tabular}{|c|c|c|}
\hline Document & Objective & Citation \\
\hline $\begin{array}{l}\text { National Policy for } \\
\text { the Elderly (May } 2010 \\
\text { reprint version) }\end{array}$ & $\begin{array}{l}\text { The national policy for the } \\
\text { elderly aims to ensure the social } \\
\text { rights of the elderly, creating } \\
\text { conditions to promote their } \\
\text { autonomy, integration and } \\
\text { effective participation in society }\end{array}$ & $\begin{array}{l}\text { BRAZIL. Law } 8.842 \text { of January 04, } \\
\text { 1994. Provides on the national policy of } \\
\text { the elderly, creates the national council of } \\
\text { the elderly and other provisions. Official } \\
\text { Gazette, Brasilia, DF, } 05 \text { Jan, 1994, p. } 77 \text {. }\end{array}$ \\
\hline Statute for the Elderly & $\begin{array}{l}\text { The Statute for the Elderly is } \\
\text { instituted, aimed at regulating } \\
\text { the rights ensured to people aged } \\
60 \text { (sixty) years or more }\end{array}$ & $\begin{array}{l}\text { BRAZIL, Law } 10.741 \text {, of October } 01 \text {, } \\
\text { 2003. Provides on the Statute of the } \\
\text { Elderly and other provisions. Official } \\
\text { Gazette of the Union, Brasília, DF, } \\
\text { Section 1, October 03, 2003, p.1. }\end{array}$ \\
\hline $\begin{array}{l}\text { International Plan of } \\
\text { Action on Ageing }\end{array}$ & $\begin{array}{l}\text { Instrument for the formulation } \\
\text { of policies that guarantee aging } \\
\text { with security, dignity, and } \\
\text { participation with full rights. }\end{array}$ & $\begin{array}{l}\text { UNITED NATIONS } \\
\text { ORGANIZATION. International plan } \\
\text { of action on ageing. Translation by Arlene } \\
\text { Santos, revision of Portuguese by Alkmin } \\
\text { Cunha; technical revision by Jurilza M.B. } \\
\text { de Mendonça and Vitória Gois. - Brasília: } \\
\text { Special Secretariat for Human Rights, } \\
\text { 2003. } 86 \text { p. }\end{array}$ \\
\hline $\begin{array}{l}\text { Active Aging: a health } \\
\text { policy }\end{array}$ & $\begin{array}{l}\text { Health Policy Project seeks to } \\
\text { provide information for } \\
\text { discussion and formulation of } \\
\text { action plans that promote active } \\
\text { healthy aging. }\end{array}$ & $\begin{array}{l}\text { World Health Organization. Active } \\
\text { aging: a health policy / World Health } \\
\text { Organization; translation Suzana } \\
\text { Gontijo. - Brasília: Pan-American Health } \\
\text { Organization, 2005. 60p. }\end{array}$ \\
\hline $\begin{array}{l}\text { National Health } \\
\text { Policy for the Elderly }\end{array}$ & $\begin{array}{l}\text { Approve the National Policy for } \\
\text { the Health of the Elderly }\end{array}$ & $\begin{array}{l}\text { BRAZIL. Ordinance No. 2.528, October } \\
\text { 19, 2006. Approves the National Policy } \\
\text { for the Health of the Elderly. Official } \\
\text { Gazette of the Union, Brasília, DF, } \\
\text { October 20, 2006. Section 1, p. } 142 .\end{array}$ \\
\hline $\begin{array}{l}\text { Health care for the } \\
\text { elderly and aging }\end{array}$ & $\begin{array}{l}\text { Providing the basis for } \\
\text { professionals, managers, students, } \\
\text { and educational and research } \\
\text { institutions involved with the } \\
\text { theme and with the commitment } \\
\text { to better care for the elderly and } \\
\text { strengthens the commitments } \\
\text { made by the } 2006 \text { Pact for Health }\end{array}$ & $\begin{array}{l}\text { BRAZIL. Ministry of Health. Health } \\
\text { Care Secretariat. Department of } \\
\text { Programmatic and Strategic Actions. } \\
\text { Health care for the elderly and aging. } \\
\text { Brasília, 2010. } 44 \text { p.: il. - (Series B. Basic } \\
\text { Health Texts) (Pacts for Health Series } \\
\text { 2006, v. 12) }\end{array}$ \\
\hline
\end{tabular}

to be continued... 


\begin{tabular}{ll}
\hline Document & Objective \\
\hline $\begin{array}{l}\text { Basic Health Care } \\
\text { Booklet: Aging and } \\
\text { Health of the Elderly }\end{array}$ & $\begin{array}{l}\text { Resolving the needs of the elderly } \\
\text { population in Primary Care }\end{array}$ \\
& \\
Health Pact & $\begin{array}{l}\text { Approve the Operational } \\
\text { Guidelines of the 2006 Health } \\
\end{array}$ \\
& $\begin{array}{l}\text { Pact - Consolidation of the UHS } \\
\text { with its three components: Pacts } \\
\text { for Life, in Defense of UHS and } \\
\text { Management. }\end{array}$
\end{tabular}

State Law regarding the elderly

A Practical Guide for the Caregiver

\section{Caring Better and Preventing Violence - Manual for the Caregiver of the Elderly}

Surveillance and
prevention of falls in
the elderly

To guide caregivers in the health care of people of any age, bedridden or with physical limitations who need special care elderly

Instrumentalize formal and informal caregivers in their to violence against the elderly and help in the formation or training of caregivers

Contribute to the development of models and techniques of action in the prevention of falls and the production of advances to face the situation related to the grievance and to impact on its reduction.
State legislation relating to the qualification and confrontation

\section{Citation}

BRAZIL. Ministry of Health. Secretariat of Health Care. Department of Basic Care. Aging and health of the elderly. Brasília: Ministry of Health, 2006. 192 p. il. (Series A. Norms and Technical Manuals) ( Basic Health Care Booklets, n. 19)

BRAZIL. Ordinance No. 399 of February 22, 2006. Discloses the 2006 Health Pact - Consolidation of UHS and approves the Operational Guidelines of said Pact. Official Gazette of the Union, Brasilia, DF, 23 February 2006, section 1, p. 43.

SÃO PAULO (State). Law 12.548 of February 27, 2007. Consolidates the legislation for the elderly. Official Gazette of the State of São Paulo, São Paulo, SP, 28 Feb. 2007, section I, vol. 117, n. 39, p. 1-4.

BRAZIL. Ministry of Health. Health Care Secretariat. Secretariat of Work Management and Health Education. Practical Guide for the Caregiver. Brasília: Ministry of Health, 2008. 64 p.: il. - (Series A. Norms and Technical Manuals)

BRASIL. Special Secretariat for Human Rights, Undersecretariat for the Promotion and Defense of Human Rights. Better Caring and Avoiding Violence - Handbook for the Caregiver of the Elderly / Tomiko Born (organizer) Brasília, 2008. 330 p.; $30 \mathrm{~cm}$

SÃO PAULO (State). Health Secretariat. Surveillance and prevention of falls in the elderly. Editors: Marilia C. P. Louvison and Tereza Etsuko da Costa Rosa - São Paulo: SES/SP, 2010.

to be continued... 


\begin{tabular}{|c|c|c|}
\hline Document & Objective & Citation \\
\hline $\begin{array}{l}\text { National } \\
\text { Commitment to } \\
\text { Active Aging }\end{array}$ & $\begin{array}{l}\text { Establishes the National } \\
\text { Commitment to Active Aging } \\
\text { and creates an Interministerial } \\
\text { Commission to monitor and } \\
\text { evaluate actions in its scope } \\
\text { and to promote the articulation } \\
\text { of public agencies and entities } \\
\text { involved in its implementation. }\end{array}$ & $\begin{array}{l}\text { BRAZIL. Decree } 8,114 \text { of September } \\
\text { 30, 2013. Establishes the National } \\
\text { Commitment to Active Aging and creates } \\
\text { the Interministerial Commission to } \\
\text { monitor and evaluate actions within its } \\
\text { scope and promote the coordination of } \\
\text { public agencies and entities involved in } \\
\text { its implementation. Official Gazette of } \\
\text { the Union, Brasília, DF, October 1, 2013, } \\
\text { section 1, page } 1 \text {. }\end{array}$ \\
\hline $\begin{array}{l}\text { Health Booklet for } \\
\text { the Elderly }\end{array}$ & $\begin{array}{l}\text { Qualify the care offered to the } \\
\text { elderly in the Brazilian National } \\
\text { Health System }\end{array}$ & $\begin{array}{l}\text { BRAZIL. Ministry of Health. Health } \\
\text { Care Secretariat. Department of } \\
\text { Specialized and Thematic Care. } \\
\text { Handbook of the Health of the Elderly. } 4 \\
\text { ed. Brasília, 2017. } 61 \text { p. }\end{array}$ \\
\hline
\end{tabular}

Source: own elaboration.

The publications had different presentation and language profiles in accordance with the target group and were categorized according to their specificity in relation to the issuing source and information from the contextual analysis of the content regarding the nature, characteristic of its scope, target population and how the issue of falls is addressed.

Table 2. List of documents analyzed according to characteristic, nature, target audience, and specificity of the falls theme. Ribeirão Preto-SP, 2019

\begin{tabular}{lllll}
\hline Document & $\begin{array}{l}\text { Source } \\
\text { characterization and } \\
\text { general appearance }\end{array}$ & $\begin{array}{l}\text { Nature/ } \\
\text { Characteristic }\end{array}$ & $\begin{array}{l}\text { Target } \\
\text { Audience }\end{array}$ & $\begin{array}{l}\text { Specificity of the } \\
\text { theme Falls }\end{array}$ \\
$\begin{array}{l}\text { National Health } \\
\text { Policy for the } \\
\text { Elderly }\end{array}$ & $\begin{array}{l}\text { Health - Ministry of } \\
\text { Health }\end{array}$ & $\begin{array}{l}\text { Health Policy/ } \\
\text { Management }\end{array}$ & $\begin{array}{l}\text { Managers } \\
\text { / health } \\
\text { professionals }\end{array}$ & $\begin{array}{l}\text { No reference to the } \\
\text { topic }\end{array}$ \\
$\begin{array}{l}\text { Elderly Statute } \\
\text { Social - Human }\end{array}$ & $\begin{array}{l}\text { Juridical-Legal/ } \\
\text { Rights Secretariat }\end{array}$ & $\begin{array}{l}\text { Muman Rights } \\
\text { Managers/ } \\
\text { society }\end{array}$ & $\begin{array}{l}\text { No reference to the } \\
\text { topic }\end{array}$ \\
$\begin{array}{l}\text { National Policy for } \\
\text { the Elderly }\end{array}$ & $\begin{array}{l}\text { Health - Legislative } \\
\text { Branch }\end{array}$ & $\begin{array}{l}\text { Health Policy/ } \\
\text { Management }\end{array}$ & Managers & $\begin{array}{l}\text { The topic is the } \\
\text { focus of a directive } \\
\text { with relevance }\end{array}$ \\
& & & & to be continued...
\end{tabular}




\begin{tabular}{|c|c|c|c|c|}
\hline $\begin{array}{l}\text { A Practical Guide } \\
\text { for the Caregiver }\end{array}$ & $\begin{array}{l}\text { Health - } \\
\text { Ministry of Health }\end{array}$ & $\begin{array}{l}\text { Care Technique/ } \\
\text { Guidance }\end{array}$ & Caregivers & $\begin{array}{l}\text { The theme is } \\
\text { a milestone } \\
\text { pointed out in the } \\
\text { document }\end{array}$ \\
\hline $\begin{array}{l}\text { Better Care and } \\
\text { Prevention of } \\
\text { Violence }\end{array}$ & $\begin{array}{l}\text { Health - Human } \\
\text { Rights Secretariat }\end{array}$ & $\begin{array}{l}\text { Care Technique/ } \\
\text { Guidance and } \\
\text { Human Rights }\end{array}$ & $\begin{array}{l}\text { Caregivers } \\
\text { / health } \\
\text { professionals }\end{array}$ & $\begin{array}{l}\text { The theme is } \\
\text { a milestone } \\
\text { pointed out in the } \\
\text { document }\end{array}$ \\
\hline $\begin{array}{l}\text { Health Care for } \\
\text { the Elderly and } \\
\text { Aging }\end{array}$ & $\begin{array}{l}\text { Health - } \\
\text { Ministry of Health }\end{array}$ & $\begin{array}{l}\text { Health Policy } \\
\text { and Technique/ } \\
\text { Management }\end{array}$ & $\begin{array}{l}\text { Managers } \\
\text { / health } \\
\text { professionals }\end{array}$ & $\begin{array}{l}\text { The topic is the } \\
\text { focus of a guideline }\end{array}$ \\
\hline $\begin{array}{l}\text { Health Booklet for } \\
\text { the Elderly }\end{array}$ & $\begin{array}{l}\text { Health - } \\
\text { Ministry of Health }\end{array}$ & $\begin{array}{l}\text { Assistance } \\
\text { technique/ } \\
\text { Guidance }\end{array}$ & $\begin{array}{l}\text { Health } \\
\text { professionals }\end{array}$ & $\begin{array}{l}\text { The theme is } \\
\text { a milestone } \\
\text { pointed out in the } \\
\text { document }\end{array}$ \\
\hline Health Pact & $\begin{array}{l}\text { Health - } \\
\text { Ministry of Health }\end{array}$ & $\begin{array}{l}\text { Health Policy/ } \\
\text { Management }\end{array}$ & $\begin{array}{l}\text { Managers } \\
\text { / health } \\
\text { professionals }\end{array}$ & $\begin{array}{l}\text { No reference to the } \\
\text { topic }\end{array}$ \\
\hline $\begin{array}{l}\text { Surveillance and } \\
\text { prevention of falls } \\
\text { in the elderly }\end{array}$ & $\begin{array}{l}\text { Health - } \\
\text { Health Department } \\
\text { of the State of São } \\
\text { Paulo }\end{array}$ & $\begin{array}{l}\text { Assistance } \\
\text { techniquel } \\
\text { Guidance }\end{array}$ & $\begin{array}{l}\text { Health } \\
\text { professionals }\end{array}$ & $\begin{array}{l}\text { The objective of } \\
\text { the document is to } \\
\text { discuss the theme }\end{array}$ \\
\hline $\begin{array}{l}\text { Active Aging: a } \\
\text { health policy }\end{array}$ & $\begin{array}{l}\text { Health - Pan } \\
\text { American Health } \\
\text { Organization }\end{array}$ & $\begin{array}{l}\text { Health Policy/ } \\
\text { Management }\end{array}$ & $\begin{array}{l}\text { Health } \\
\text { professionals / } \\
\text { Managers }\end{array}$ & $\begin{array}{l}\text { The theme is } \\
\text { a milestone } \\
\text { pointed out in the } \\
\text { document }\end{array}$ \\
\hline $\begin{array}{l}\text { International } \\
\text { Plan of Action on } \\
\text { Ageing }\end{array}$ & $\begin{array}{l}\text { Health - Human } \\
\text { Rights Secretariat }\end{array}$ & $\begin{array}{l}\text { Health Policy/ } \\
\text { Management }\end{array}$ & Managers & $\begin{array}{l}\text { No reference to the } \\
\text { topic }\end{array}$ \\
\hline Decree 8.114/13 & $\begin{array}{l}\text { Health - Legislative } \\
\text { Power }\end{array}$ & $\begin{array}{l}\text { Health Policy/ } \\
\text { Management and } \\
\text { Human Rights }\end{array}$ & Managers & $\begin{array}{l}\text { No reference to the } \\
\text { topic }\end{array}$ \\
\hline Law 12.548/07 & $\begin{array}{l}\text { Health - Legislative } \\
\text { Assembly of the State } \\
\text { of São Paulo }\end{array}$ & $\begin{array}{l}\text { Juridical- } \\
\text { Legal/Health } \\
\text { Management }\end{array}$ & Managers & $\begin{array}{l}\text { No reference to the } \\
\text { topic }\end{array}$ \\
\hline Basic Care Booklet & $\begin{array}{l}\text { Health - } \\
\text { Ministry of Health }\end{array}$ & $\begin{array}{l}\text { Policy and } \\
\text { Technical/ } \\
\text { Assistance } \\
\text { Guidance }\end{array}$ & $\begin{array}{l}\text { Health } \\
\text { professionals }\end{array}$ & $\begin{array}{l}\text { The theme is a } \\
\text { milestone pointed } \\
\text { out in the document } \\
\text { in relevance }\end{array}$ \\
\hline
\end{tabular}

Source: own elaboration. 
As disposed above, the publications are categorized according to their nature:

- Policies - normative that enumerate administrative responsibilities and functions at the national level. In this category, six publications (43\%) were identified as political in nature and two (14\%) as mixed.

- Juridical-Legal - are legal instruments in which legislation and jurisprudence are included and refer to norms or decisions. Two (14\%) documents were included.

- Technique - includes technical discussions, specific to the health area. Four publications (28\%) were considered of a technical nature and two of a mixed nature (14\%).

Regarding the main characteristic:

- Health management - guidelines on the institutional actions and commitments and of each governmental sphere. Half of the documents were allocated to this category, seven (50\%), and one was considered to have a mixed characteristic (7\%).

- Human rights - Standards for social protection of the elderly. They were represented by one standard (7\%) and two mixed ones (14\%).

- Care Guidance - practical exposure on the subject with simplified language. There were only two documents (14\%) for guidance to formal and informal caregivers and lay public.

- Assistance guidance - more comprehensive or in-depth exposition of health care. Alludes to three standards (21\%). Intended for use by health professionals, especially in Primary Care.

As for the specificity of the theme falls and its relevance in the documents, these were categorized according to exposure:

- No reference to the topic: the term falls is not mentioned. Six publications (43\%) were considered. In some of them, there are goals to facilitate the locomotion of the elderly, but they do not mention falls directly.

- The topic is the focus of a guideline: falls are mentioned in a single topic, but within a context such as violence, accidents, or educational actions. Only two documents are in this category (13\%).

- The theme is a milestone pointed out in the document: falls occupy a topic of discussion, where causes and interventions are more explored. Five publications (33\%) are considered here. 
- The objective of the document is to discuss the theme: the documents are specific in the exposition and discussion on the theme. One document (7\%) details about falls, causes, interventions and preventions.

Table 3. Description of the themes identified in the document analysis. Ribeirão PretoSP, 2019

Document Falls

Taking better care of and avoiding violence - Falls are frequent and bring several consequences. It Special Secretariat for Human Rights, 2008 presents the intrinsic and extrinsic causes.

National Health Policy for the Elderly Ministry of Health, 2006

Statute for the Elderly - Legislative, 2003

Practical Guide for the Caregiver - Ministry These are the accidents that occur the most in the of Health, 2008 elderly

Health Care for the Elderly and Aging - $\quad$ Fall is a public health problem.

Ministry of Health, 2010

Health Booklet for the Elderly - Ministry of They are frequent and can be avoided.

Health, 2014

Health pact - Ministry of Health, 2006

Surveillance and prevention of falls in the elderly - State of São Paulo, 2010

Presents the epidemiology of falls and its relation to intrinsic and extrinsic risks.

Active aging: a health policy - World Health Falling is made up of many preventable causes and Organization, 2005 is responsible for frequent injuries, treatment costs, and deaths for this age group

International Plan of Action on Ageing -

United Nations, 2003

National Commitment to Active Aging -

Legislative, 2013

National Policy for the Elderly - Legislative, 1994

It approaches falls as a point of confluence between violence and accidents. Addresses the morbidity and mortality from falls in the country in a relevant way.

Law 12.548 de 2007 - State of São Paulo

Primary Care Booklet n. 19 - Ministry of Health, 2006

Specifies the epidemiology of falls and extrinsic and intrinsic causes

Source: own elaboration. 


\section{Discussion}

Starting from the historical evolution, it is observed, at first, that the legislations had a protectionist design, in which the elderly were considered frail and in need of support. Thus, publications from the Legislative Branch, such as the National Policy of the Elderly (1994) and the Statute of the Elderly (2003) have a characteristic of social support (ROSA; BARROSO; LOUVISON, 2013). Imbued also with this intention, the International Plan of Action on Aging (2003) endorses objectives and management.

Also significant was the publication of the World Health Organization in 2002, called Active aging: a policy framework, which originated the publication in Portuguese "Envelhecimento Ativo: uma política de saúde" (2005). It was a landmark that guided public policies and legislation internationally on health, being the first publication on aging in Brazil by the Ministry of Health. In this publication, the perspective of the genesis and incidence of diseases and illnesses is modified, coming from intersectorial and diverse determinants such as economic conditions, physical and social environments, management and access to health care, safety, among others.

Another important conception presents the elderly as a protagonist and active agent and fundamental for the maintenance of health promotion, influenced by lifestyle and balanced nutrition, for example, which change the quality of life and result in an active aging. Although falls are associated with the physical environment at home in the document, it can be said that its prevention factors in this document also include factors inherent to the protagonism and autonomy of the elderly, such as the proper use of medications, physical activities, abandonment of alcoholism, among others.

Still on the historical evolution of the most relevant documents analyzed, it is evident the first publications of the Ministry of Health that regulated the directives in accordance with the principles of UHS and international goals. The previous publications were the primary legal pillars for the health management of the elderly in 2006: National Policy for the Health of the Elderly and the Pact for Health.

In the same year, the Basic Care Booklet: Aging and Health of the Elderly Person (2006) was the first document focused on standardizing care and included the norms of the National Policy of Basic Care (2006), National Policy on Health of the Elderly Person (2006), Pact for Health (2006), National Policy of Health 
Promotion (2006), and National Humanization Policy (2003). And following the care line, the Health Handbook for the Elderly Person (2008), the Practical Guide for the Caregiver (2008), and Caring Better and Avoiding Violence - Manual for the Caregiver of the Elderly Person (2008) were published.

The other documents continue to regulate the management, such as the publication Health Care for the Elderly and Aging (2010) and the National Commitment to Active Aging (2013). Two documents were included regarding the state of Sáo Paulo as representative of state legislations: State Law on the Elderly (12.548/07) and Surveillance and prevention of falls in the elderly (2010).

Going deeper into the topic of falls, publications aimed at management do not specify pathologies or aggravations, due to the specifications and nature of the publications. So, falls are not mentioned in design, risk factors, or epidemiological data. In these documents, such as the Decree n. 8,114/13, the Pact for Health (2006), the Law n. 12,548/07 of the State of São Paulo, and the International Plan of Action on Aging (2003), there is a predominance of goals agreed upon among the federated entities for implementation and evaluation of programs regarding the health of the elderly.

In the national policies, there are different presentations and conceptions regarding falls. In the National Policy for the Elderly (1994), health indicators of falls stand out. Alarming data such as mortality rates, hospital admissions, and hospitalization show the importance of this problem and the resulting public spending. Falls are understood as a convergence between violence and accidents, evidenced by the fact that falls are inserted in the Violence Action Plan in the document.

Distinctively, the National Policy for the Health of the Elderly (2006) does not report data on falls. And although not explicit, its conception has an accidental direction towards falls, since it is associated with obstacles in the elderly's residential environment, on public roads, and in urban transportation.

The Primary Health Care Booklet (2006), which fulfilled the need to base the assistance of professionals in primary care on the health of the elderly, stands out. The document, although technical, has a clear language for everyone and describes falls as a public health problem with epidemiological data, associated factors, and consequences.

The publications Better Care and Violence Prevention (2008), Practical Guide for the Caregiver (2008), and the Health Handbook for the Elderly (2017) are tools 
and documents to educate caregivers and family members about everyday aspects and assist in caregiving. In simple language, they describe in a succinct and practical way the falls and the factors that influence their incidence, especially the adaptation of the home environment.

To quantify falls, the health indicator used is the Rate of Hospitalizations for Fracture of the Femur, which is described by the document Attention to the Health of the Elderly and Aging (2010). This publication details the components of the pact proposed in the Health Pact for the elderly.

The document prepared by the Health Department of the State of São Paulo, called Surveillance and Prevention of Falls in the Elderly (2010), is complete. It presents a discussion on policies for the health of the elderly, describes in detail data on health indicators for falls, risk factors, prevention actions, among others.

In summary, as for documents of a technical nature, their emphasis is on the assistance provided by primary care. Their main focus, in general, is on health professionals, formal and informal caregivers, family members, and the elderly themselves.

The perception about falls presented by the publications is that they are accidental occurrences, according to the concepts described. On the other hand, the documents point out that preventive actions allow a decrease in the incidence of falls, mostly through awareness of the problem, health education, training of multidisciplinary teams and urban and home environmental adaptation.

However, it is emphasized that preventive actions on falls should not be limited to the care of already established pathologies or to the physical space; on the contrary, they require a holistic and integral scope, since falls are the result of a complex multifactorial interaction. Even essential interventions, such as home adaptation, require a social network, information about the importance of falls and related risk factors, guidance about the architectural structures to be changed, and financial conditions. Therefore, each action also encompasses communication, education, and teamwork (PORTELLA; LIMA, 2018).

Therefore, it is understood that health promotion interventions, which include falls prevention, are multidimensional, since aging is the result of a lifetime construction and the comprehensive care of the elderly includes emotional and instrumental support, social inclusion and participation, economic status, 
environmental conditions, access to health services at all levels of care, functional and cognitive development (VERAS et al., 2013).

Public policies, as presented, are in agreement with these proposals for disease prevention, but it is observed that they lack expansion in all the aspects described and strengthening for implementation, especially in primary care, resulting from a dialogue between the elderly, families, the population and government sectors.

The panorama of this research on falls from the perspective of public policies revealed that it is a great challenge to encompass all dimensions included in the prevention of falls. Consequently, its effectiveness through public policies makes it possible to decrease the incidence of falls, reduce public expenses, maintain functional capacity, quality of life, and active aging. It is worth trying.

\section{Final considerations}

The official publications analyzed here are considered as proposals of governmental interventions when facing conjunctures of negative impact on a population. This research aims to identify the relevance of falls in the elderly and understand how the phenomenon is portrayed in public policies aimed at the care of the elderly.

It was identified that falls are found significantly in official publications aimed at health professionals and caregivers. It is noteworthy that falls are portrayed as an important public health problem within this population segment, and the potential decreases in incidence rates and morbidity and mortality due to preventive actions are highlighted.

The expectation is that this research will contribute to the evaluation of current public policies in the sense of portraying a picture about the theme, and in the same way educate about the theme among health professionals and managers. ${ }^{1}$

\section{References}

ABREU, D.R.O.M.; NOVAES, E.S.; OLIVEIRA, R.R.; MATHIAS, T.A.F.; MARCON, S.S. Internação e mortalidade por quedas em idosos no Brasil: análise de tendência. Ciênc. saúde colet., v.23, n.4, abr. 2018. https://doi.org/10.1590/1413-81232018234.09962016

ARAÚJO NETO, A.H.; PATRÍCIO, A.C.F.A.; FERREIRA, M.A.M.; RODRIGUES, B.F.L.; SANTOS, T.D.; RODRIGUES T.D.B. et al. Falls in institutionalized older adults: risks, consequences and antecedents. Rev Bras Enferm., v.79, n.4, p.719-725, 2017. http://dx.doi. org/10.1590/0034-7167-2017-0107 
BAIXINHO, C.L.; DIXE, M.A. Construction and Validation of the Scale of Practices and Behaviors of Institutionalized Elderly to Prevent Falls. Universal Journal of Public Health, v. 4, n.3, p. 139-143, 2016. http://dx.doi.org/10.13189/ujph.2016.040303.

BARROS, L.F.O.; PEREIRA, M.B.; WEILLER, T.H.; ANVERSA, E.T.R. Internaçóes hospitalares por quedas em idosos brasileiros e os custos correspondentes no âmbito do Sistema Único de Saúde. Revista Kairós Gerontologia, v. 18, n.4, p.63-80, out-dez 2015. Disponível em: <https://revistas.pucsp.br/kairos/article/view/26930/19124>.

CAMARA, R.H. Análise de conteúdo: da teoria à prática em pesquisas sociais aplicadas às organizaçôes. Gerais, Rev. Interinst. Psicol., Belo Horizonte, v. 6, n. 2, p. 179-191, jul. 2013. Disponível em <http://pepsic.bvsalud.org/scielo.php?script=sci_arttext\&pid=S1983$82202013000200003 \& \operatorname{lng}=$ pt $\&$ nrm $=$ iso $>$.

FALSARELLA, A.M. O lugar da pesquisa qualitativa na avaliação de políticas e programas sociais. Avaliação, v. 20, n. 3, p. 703-715, nov. 2015. http://dx.doi.org/10.1590/S141440772015000300009

MACEDO, A.S.; ALCÂNTARA, V.C.; ANDRADE, L.F.S.; FERREIRA, P.A. O papel dos atores na formulação e implementação de políticas públicas: dinâmicas, conflitos e interesses no Programa Mais Médicos. Cadernos EBAPE.BR, v.14, ed. Especial, artigo 10, Jul 2016. http:// dx.doi.org/10.1590/1679-395117188

ORGANIZAÇÃO MUNDIAL DA SAÚDE. Relatório Mundial de Envelhecimento $e$ Saúde - Resumo. Genebra: WHO, 2015. Disponível em: < http://sbgg.org.br/wp-content/ uploads/2015/10/OMS-ENVELHECIMENTO-2015-port.pdf>.

PORTELLA, M. R.; LIMA, A. P. de. Quedas em idosos: reflexões sobre as políticas públicas para o envelhecimento saudável. Arq. Cienc. Saúde UNIPAR, Umuarama, v. 22, n. 2, p. 109115, maio/ago. 2018. http://dx.doi.org/10.25110/arqsaude.v2212.2018.6366

RESENDE, J.A.; LOPES, R.G.C.; MANSO, M.E.G. Apontamentos sobre a história das políticas públicas sobre envelhecimento. Revista Portal de Divulgação, n. 55, ano VIII, janfev 2018. Disponível em: < https://revistalongeviver.com.br/index.php/revistaportal/article/ view/694/764>.

ROSA, T.E.C.; BARROSO, A.E.S.; LOUVISON, M.C.P. Introdução. In: (Org.). Velhices: experiências e desafios nas políticas do envelhecimento ativo. São Paulo: Instituto de Saúde. Secretaria de Saúde do Estado de São Paulo, 2013. p. 13-26. (Temas em Saúde Coletiva). SHERRINGTON, C.; MICHALEFF, Z.A.; FAIRHALL, N.; PAUL, S.S.; TIEDEMANN, A.; WHITNEY, J.C.; CUMMING, R.G.; HERBERT, R.D.; CLOSE, J.C.T.; LORD, S.R. Exercise to prevent falls in older adults: An updated systematic review and meta-analysis. British Journal of Sports Medicine, out 4, 2016. http://dx.doi.org/ 10.1136/bjsports-2016-096547. 
SILVA, A.H.; FOSSÁ, M.I.T. Análise de conteúdo: exemplo de aplicação da técnica para análise de dados qualitativos. Qualitas Revista Eletrônica, v. 17, n. 1, 2015. Disponível em: < http:// revista.uepb.edu.br/index.php/qualitas/article/view/2113/1403>.

STENHAGEN, M.; EKSTRÖM, H.; NORDELL, E.; SÖLVE, E. Accidental falls, healthrelated quality of life and life satisfaction: A prospective study of the general elderly population. Archives of gerontology and geriatrics, v. 58, issue 1, p. 965-100, jan-fev 2014. https://doi. org/10.1016/j.archger.2013.07.006.

TOLEDO, A.A.S.F; NITRINI, R.; BOTTINO, C.M.C; CARAMELLI, P. Brazilian research on cognitive impairment and dementia from 199 to 2013. Dement. Neuropsychol, v. 8, n. 4, p. 394-398, 2014. http://dx.doi.org/10.1590/S1980-57642014DN84000015.

VERAS, R.P.; CALDAS, C.P.; CORDEIRO, H.A. Modelos de atenção à saúde do idoso: repensando o sentido da prevençáo. Physis, Rio de Janeiro, v. 23, n. 4, p. 1189-1213, Dec. 2013. http://dx.doi.org/10.1590/S0103-73312013000400009.

\section{Note}

${ }^{1}$ R. F. M. dos R. Fonseca: manuscript conception and writing. S. Matumoto: research guidance. 


\section{Resumo}

\section{Panorama das quedas nas politicas públicas brasileiras}

As políticas públicas retratam as propostas de açōes sobre circunstâncias que afetam a população desfavoravelmente. As quedas representam um fator importante de morbimortalidade e prejuízos ao envelhecimento. Assim, o objetivo da pesquisa foi delinear o panorama das quedas na esfera governamental por meio da análise e identificar sua relevância nas publicaçóes oficiais. A pesquisa, qualitativa de análise documental, partiu da análise de conteúdo de 14 documentos e verificou que as quedas são abordadas de forma concisa, na maior parte dos documentos e destinada aos profissionais de saúde. Ressalta-se que as quedas são destacadas como ocorrências preveníveis e passíveis de intervenção por parte dos próprios idosos, familiares, profissionais de saúde e gestores.

Palavras-chave: idoso; acidentes por quedas; documento governamental. 